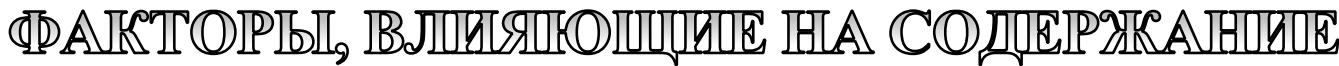

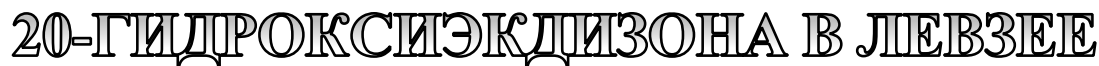

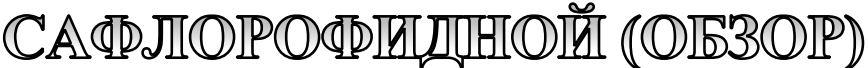

\section{М.А. Соловьева, Пермский научно-исследовательский институт сельского хозяйства}

Представлены данные, опубликованные в период с 2005 по 2019 г., посвященные изучению влияния факторов абиотической среды (температуры, влажности, освещенности, почвы), антропогенного воздействия (условий выращивания, удобрений, регуляторов роста, условий заготовки, сушки и хранения), а также вегетации, онтогенеза и других условий на содержание 20-гидроксиэкдизона в левзее сафлоровидной. Левзея сафлоровидная (Rhaponticum carthamoides (Willd.) Iljin) - перспективное кормовое растение, обладающее иммуностимулирующими и иммуномодулирующими свойствами и положительно влияющее на обменные процессы. Актуально изучение фракторов и условий, которые способствуют как естественному биосинтезу и накоплению фризиологически активных веществ в кормовых растениях, так и сохранению их исходного содержания в сырье во время процесса заготовки и хранения.

Природно-климатические условия Пермского края благоприятны для произрастания левзеи сафлоровидной. Предполагается, что можно регулировать содержание $20 \mathrm{E}$ в растительном материале путем создания оптимального технологического режима и набором агротехнических приёмов при культивировании. Стрессовые ситуации кратковременной длительности могут привести к увеличению содержания вторичных метаболитов в растениях как ответ на воздействие окружающей среды.

Ключевые слова: левзея сафлорофидная, Rhaponticum carthamoides, 20-гидроксиэкдизон, 20-hydroxyеcdysone, факторы абиотической и биотической среды.

Левзея сафлорофидная (Rhaponticum carthamoides (Willd.) IIjin, maral root, paпонтикум сафлоровидный, маралий корень, маралова трава, большеголовник альпийский) - является перспективным кормовым растением. Наземная масса Rhaponticum carthamoides (Willd.) IIjin может быть высокоэффективным источником кормов. Преимущество этой культуры в кормопроизводстве заключается не только в раннем получении зелёной массы и её кормовых качествах, но и в иммуностимулирующих и иммуномодулирующих свой- ствах, положительно влияющих на обменные процессы в организме, а также на продуктивные и воспроизводительные функции животных $[4$, с. $52 ; 15$, c. 21$]$. Промышленные технологии содержания животных, не всегда оптимальные, техногенная и антропогенная нагрузки могут приводить к стрессам сельскохозяйственных животных, снижению иммунной функции их организма и заболеваниям. Возникает необходимость применения антибиотиков, гормонов и других специфических биологически активных 
веществ, что не всегда безопасно как для животных, так и для человека $[17$, с. 13].

В настоящее время усиливается контроль над содержанием ветеринарных лекарственных средств (фармакологически активных веществ) в продукции животного происхождения, в том числе вводятся ограничения на содержание антибиотиков. Таким образом, становится актуальным применение новых методов профилактики заболеваний, повышения естественной резистентности организма и обеспечения высокого иммунного статуса, например, за счет включения в рацион кормления животных источников иммуностимулирующих веществ природного происхождения.

Особенно важен поиск и исследование культур, являющихся сырьем для полноценных высокопитательных кормов и сочетающих в себе как кормовые, так и иммуностимулирующие свойства. К таким культурам относится левзея сафлоровидная. Противопоказаний, серьезных побочных эффектов и осложнений после применения препаратов левзеи сафлоровидной не установлено [3, с. 240].

Физиологическая активность левзеи сафлоровидной обусловлена наличием экдистероидов (полигидроксилированных стеринов), флавоноидов, танинов, макрои микроэлементов, витаминов, аминокислот и др. $[7$, с. $50 ; 8$, с. $21 ; 13$, с. 59 ; 14 , с. $335 ;$ с. 23,$37 ; 34$, с. 842 ]. Значимую роль в биологической активности кормов из левзеи сафлорофидной играют экдистероиды. Содержание экдистероидов на 97-99\% представлено высокоактивными экдистероном (синонимы: $\beta$-экдизон, 20-гидроксиэкдизон, 20-hydroxyecdysone, 20Е) [2, c. $45 ; 34$, с. 842]. Экдистероиды в пределах растения и во времени распределены неравномерно, важно знать, как реализуются потенциальные возможности накопления активных веществ в хозяйственно значимых элементах биомассы при разных условиях роста и в зависимости от разных факторов.

Целью исследования являлось изучение публикаций о процессах и факторах, влияющих на биосинтез и накопление 20-гидроксиэкдизона в левзее сафлоровидной, что актуально при выборе оптимальных условий выращивания экдистероидосодержащего растения и планировании дальнейшей экспериментальной работы. Для анализа использовали данные научных публикаций за период с 2005 по 2019 год, полученные в различных географических регионах, российских и зарубежных авторов.

Выделяют несколько групп факторов и процессов, от которых может зависеть содержание вторичных метаболитов, среди них экологические факторы, стрессовые факторы, биологические особенности растений. В числе экологических факторов, влияющих на растения, рассмотрим абиотические, к которым относят климатические, почвенно-грунтовые и топографические.

Климатические факторы (освещенность, температура, влажность и др.), влияя на рост и направленность обменных процессов в растениях, способны изменять биосинтез и накопление активных веществ в растительном сырье.

Свет и освещенность - одни из важных факторов роста растений. В условиях Предуралья изучена фотосинтетическая деятельность левзеи сафлоровидной и сделан вывод о том, что природно-климатические условия Предуралья благоприятны для произрастания и активной фотосинтетической деятельности левзеи сафлоровидной [17, с. 14]. В Архангельской области для роста растений оптимальным считают сочетание освещенности 7-120 тыс. лк, температуры $12-25^{\circ} \mathrm{C}$, влажности воздуха 40-80\% и влажности почвы 9-16\%, а при освещенности 150-160 тыс. лк и температурах $25-30^{\circ} \mathrm{C}$ наблюдали ингибирование роста побегов [31, с. 104]. Воздействие спектра освещения на содержание экдистероидов в листьях левзеи было представлено в научных работах конца 80-х годов $[31$, c. 98$]$. Левзея сафлоровидная относится к группе растений, хорошо адаптированной к изменению фотосинтетической активной радиации, используемой растениями для фотосинтеза, обога- 
щенность спектра освещения красным светом способствует накоплению экдистероидов в листьях.

Фактор температуры. Левзея сафлоровидная характеризуется высокой зимостойкостью и долголетием. По результатам исследований, проведенных в Пермском крае, установлено, что при весенних заморозках листья левзеи сафлоровидной выдерживали температуру от -8 до $-11^{\circ} \mathrm{C}$. Осенью морозостойкость листьев снижалась, они погибали при температуре от -5 до $-8^{\circ} \mathrm{C}[15$, c. 21$]$. Схожие данные наблюдали и в Архангельской области: растение выдерживало заморозки интенсивностью до $-5^{\circ} \mathrm{C}$ без видимых последствий, но при более низких температурах, от -8 до $-10^{\circ} \mathrm{C}$, отмечали небольшое повреждение апикальной зоны роста листьев, через 4-5 дней поврежденные участки листовых пластинок полностью восстанавливались, заменяясь новообразованной тканью [31, с. 100].

Выявлено, что в географически отдаленных районах, различающихся по теплообеспеченности и длине дня (таких как Польша и Архангельская область), процессы роста и развития побегов левзеи сафлоровидной идентичны. Развитие растения в условиях Польши происходит аналогично развитию в условиях Архангельской области, но со сдвигом на один месяц вперед [26, с. 306]. Содержание 20-гидроксиэкдизона во взрослых листьях в условиях Польши составляло у имматурных растений $0,036 \%$ и у виргинильных $-0,18 \%$, а в условиях Архангельской области соответственно $0,17-0,19 \%$ и $0,22 \%$. Через год содержание $20 \mathrm{E}$ в растениях из этих районов было $0,52 \%$ и $0,73 \%$ [26, с. 307].

Сделан вывод, что для формирования продуктивности и биосинтеза 20-гидроксиэкдизона теплообеспеченность района возделывания не имеет решающего значения. В условиях прохладного климата, на обедненных подзолистых почвах фитомасса левзеи сафлоровидной не уступает растениям более южных регионов на черноземах и сопровождается повышенным синтезом действующих веществ [26, 307].
В другой работе при сравнении содержания 20-гидроксиэкдизона в траве левзеи сафлоровидной двух экотипов - витебской (Северная зона Беларуси, г. Витебск) и архангельской (Европейский Север), установлено, что трава левзеи архангельского экотипа по сравнению с витебской содержит 20Е больше в 2,2 раза - 3,20\% против 1,45\%. Авторы связывают различия в накоплении экдистероидов с влиянием климатические условий [7, с. 51].

Влияние температуры на содержание $20 \mathrm{E}$ в растениях изучено на примере выращивания левзеи сафлоровидной в условиях лаборатории при разных температурах. Выявлено, что в корнях наибольшая концентрация 20Е наблюдалась при средней температуре $+15^{\circ} \mathrm{C}$ и соответствовала $0,14 \%$, а при температурах $+9^{\circ} \mathrm{C}$ и $+21^{\circ} \mathrm{C}$ содержание $20 \mathrm{E}$ было $0,05 \%$ и $0,06 \%$ [35, с. 74].

Отмечено, что условия прохладного климата действуют положительно на накопление 20-гидроксиэкдизона в надземных органах, а жаркий и сухой климат, наоборот, способствует оттоку 20-гидроксиэкдизона из наземных органов и концентрированию его в корневой системе [26, с. 307]. Таким образом, температура может влиять на перераспределение $20 \mathrm{E}$ по вертикальному профилю растения.

Фактор влажности. Установлена зависимость между содержанием 20-гидроксиэкдизона в молодых и взрослых листьях и влажностью почвы. По данным Н.П. Тимофеева, в период, когда влажность корнеобитаемого слоя почвы была в пределах 15-18\%, содержание 20Е в молодых листьях розеточных полициклических побегов с начала фазы отрастания и через 20 суток вегетации было $0,35-0,55 \%$. В июле-августе оно снижалось до $0,25-0,28 \%$, что совпадало с наступлением засушливых условий (влажность почвы около $3,0 \%$ ). В сентябре после повышения влажности почвы до 11-14\% содержание 20 Е вновь возрастало. Во взрослых листьях падение содержания 20Е также приходилось на засушливый период. Уменьшение содержания 20-гидроксиэкдизона до 
минимальных значений, как в молодых, так и во взрослых листьях совпадало с наступлением засушливых условий в летний период, и относительное восстановление происходило в начале осени при снижении дневной температуры и возрастании относительной влажности почвы [25, с. $195 ; 29$, с. $115-116]$.

Почвенные (почвенно-грунтовые) или эдафические факторы. Почва состоит из твердых минеральных и органических частиц, воды и воздуха. Она характеризуется физико-химическими свойствами механическим составом, структурой, кислотностью, плотностью, содержанием питательных веществ и солей, влажностью, степенью аэрации и др. Состав почвы может влиять не только на продуктивность сельскохозяйственных культур и различия в длительности нахождения в этапах онтогенеза, но и на количество экстрактивных веществ и концентрацию 20-гидроксиэкдизона. Исследовано влияние почвенного фактора и его составляющих на накопление экстрактивных веществ на примере левзеи сафлоровидной среднего генеративного возраста в Архангельской области. Наибольшим выходом экстрактивных веществ обладали растения, выращенные на песчаных и супесчаных почвах. Выявлено, что на богатых органическим веществом и азотом почвах содержание 20-гидроксиэкдизона во взрослых розеточных листьях в 4 и 2 раза ниже, чем на обедненных почвах: $0,11 \%$ и $0,24 \%$ против $0,42 \%$ [22, с. 288$]$.

При сравнении почв с разной кислотностью наивысшая концентрация 20-гидроксиэкдизона была при $\mathrm{pH}$ почвы 4,1 и соответствовала $0,84 \%$. Тип почв не влиял на общую закономерность содержание $20 \mathrm{E}$ в листьях убывало во время вегетации, начиная с фазы отрастания до начала цветения [22, с. 288]. Плодородие почвы для биосинтеза 20-гидроксиэкдизона не имеет решающего значения [26, с. 307].

Cтррессовые факторы. Как правило, растения обладают свойством приспосабливать свой метаболизм к изменениям ок- ружающей среды. При произрастании в нормальных условиях они синтезируют комплекс вторичных продуктов. Роль многих вторичных метаболитов заключается в защите растений в ответ на воздействие окружающей среды, и стрессовые факторы могут привести к увеличению их производства [12, с. 208].

Вызывая стресс в качестве ответа, у растений стимулируется биосинтез некоторых вторичных метаболитов. Чтобы вызвать такой ответ, можно использовать биотические (грибы, бактерии, конкуренция между растениями, животные и др.) или абиотические факторы (повышенные или пониженные температура и влажность, УФ-излучение, тяжелые металлы, засоление, электрические и магнитные поля и др.) [37, с. 616].

Наиболее распространенными абиотическими стрессорами являются снижение доступности воды, экстремальные температуры (нагрев или охлаждение), высокая концентрация солей в среде корнеобитания, снижение доступности питательных веществ в почве, избыток токсичных ионов, повышенная эвапотранспирация, уплотнение почвы, препятствующее росту корней [12, с. 204].

Обмен экдистероидов - процесс динамичный и непрерывный, стрессовые ситуации кратковременной длительности могут приводить к накоплению вторичных метаболитов [31, с. 104]. Изучено влияние стрессового фактора (заморозков) на накопление экдистероидов: в фазу отрастания заморозки приводили к торможению роста растения и масса листа не изменялась, однако при этом содержание 20 -гидроксиэкдизона увеличивалось. После прекращения заморозков масса листа увеличивалась в 2 раза и также в 2 раза возрастало содержание 20Е. При повторных заморозках - масса листа изменялась мало, а содержание 20Е вырастало в 1,61 раза - с 0,31 до 0,43\%. После повышения температуры накопление 20Е практически прекращалось. Таким образом, однофакторный эффект низких и отрицательных температур проявлялся в 
торможении роста побегов и повышении содержания экдистероидов в листьях в $1,3-2,1$ раза [31, с. 102-103]. К числу факторов, влияющих на развитие и накопление экдистероидов, отнесли заморозки до $-7-10^{\circ} \mathrm{C}[30$, с. 168$]$.

В условиях Астраханской области изучено действие другого стрессового фактора - засухи (дефицит влагообеспеченности, водный стресс): в отличие от низких температур, дефицит влаги не приводил к повышению содержания 20-гидроксиэкдизона в листьях, оно резко падало, накопление 20Е становилось отрицательным и убывало. Концентрация $20 \mathrm{E}$ начинала падать, когда снижение влажности воздуха одновременно сопровождалось уменьшением содержания влаги в почве. Сильный стресс, вызванный засушливыми условиями погоды, резко снижал уровень $20 \mathrm{E}$ до $0,11 \%$ и далее до $0,07 \%$ [31, с. 103]. В Пермском крае снижение содержания 20Е в фитомассе до $0,020 \%$ так же связали с развитием вегетативной массы в период засухи и высоких температур [20, с. 174]. Отмечена достоверная отрицательная корреляция между накоплением 20-гидроксиэкдизона и влажностью почвы, многофакторное действие водного стресса приводит к прекращению биосинтеза и оттоку экдистероидов из наземных органов [31, с. 104].

Биологические особенности растения. В нескольких работах рассмотрена динамика содержания 20-гидроксиэкдизона в левзее сафлоровидной в зависимости от стадии и фазы развития (в течение вегетационного сезона), возрастного состояния (периода развития в онтогенезе) и распределения в разных органах растения.

20 -гидроксиэкдизон найден в пробах всех органов левзеи сафлоровидной, он распределен по всему вертикальному профилю, в соцветиях, листьях, корнях. При этом в пределах растения его распределение неравномерно, в надземных частях максимальные концентрации 20Е могут достигать $0,5-1,0 \%$, в подземных $0,05-0,15 \%$ [23, с. 37]. Наивысший уровень 20Е наблюдался в семенах
(0,57-1,5\%), однако 20-гидроксиэкдизон там деактивирован жирными кислотами. Содержание $20 \mathrm{E}$ в почках - 0,3-0,4\%, в стеблях - 0,1\% [24, с. 127], листья на фоне корней в 4-10 раз богаче 20-гидроксиэкдизоном, $\quad 0,25-0,43 \%$ в листьях и $0,03-0,12 \%$ в корнях [32, с. 76].

Выявлено, что содержание 20Е возрастает от нижних метамеров к апикальным; так, в нижней части стебля его концентрация $0,10 \%$, в средней $-0,16 \%$, в верхней $-0,25 \%$, а в апикальной возрастает до $0,58 \%$ [23, с. $39 ; 29$, с. 114]. Динамика содержания 20-гидроксиэкдизона в отдельных органах согласуется с процессом перераспределения биологически активных веществ от старых органов к растущим и развивающимся органам, максимальные количества наблюдали в неразвернутых белесых, паутинисто-опушенных листьях, цветоложе и семенах. После первоначального синтеза и накопления 20гидроксиэкдизона во взрослых листьях наблюдается его перемещение в интенсивно растущие ткани и органы и обогащение им тканей, необходимых для выживания или следующей генерации [29, с. 116].

Содержание 20-гидроксиэкдизона изменяется в тканях растения в течение вегетационного сезона, более высокая концентрация характерна для ранних фаз вегетации. Определено, что в начале фазы отрастания концентрация 20Е в молодых листьях розеточных полициклических побегов достигала $0,45-0,55 \%$, через 20 суток вегетации она уменьшалась до $0,35-0,40 \%$, далее во взрослых листовых органах продолжала уменьшаться до 0,27-0,33\% и к 60-му дню вегетации снижалась до $0,17 \%$ [23, с. 39]. После этого срока происходило падение концентрации на $0,01 \%$ в каждые 10 дней вегетации [29, с. 115].

Проведены исследования по сравнению концентрации экдистероидов в разных органах растения в двух фазах вегетационного периода - бутонизации и цветения. Максимальные значения наблюдались в фазе бутонизации - начало цветения, в это время в вегетативных побегах содержание 20Е у молодых листьев $-0,35 \%$; 
в генеративных побегах у апикальной части стебля - 0,58\% и цветоложе соцветия - 0,72\%. Во время фазы цветения концентрация 20-гидроксиэкдизона понижалась во всех органах, за исключением интенсивно развивающихся: цветоложа соцветий $-1,17 \%$ и семян $0,57 \%[29$, c. 113$]$.

Отмечено, что у листьев разных возрастов содержание активных веществ разное, во взрослых листьях 20-гидроксиэкдизона было значительно меньше, чем у молодых, в старых - еще меньше, а в отмерших только $0,05-0,02 \%$. В молодых полуразвернутых листьях при увеличении массы листа в 3-8 раз количество 20Е снижалось, но незначительно до 0,31-0,35\%. Во взрослых листьях количество $20 \mathrm{E}$ во время прохождения вегетационного периода снижалось с 0,38 до $0,12 \%$. В старых листьях наблюдалось равномерное снижение $20 \mathrm{E}$ с 0,15 до $0,02 \%$ независимо от фазы или календарных сроков развития растений [29, с. 113-115].

В результате других исследований замечено, что содержание $20 \mathrm{E}$ в наземной части достигало $0,60 \%$ в фазе отрастания, а в корнях в зависимости от фенофазы, содержание экдистерона стабильно $(0,18-0,30 \%)$ и достигало максимума в фазу покоя (октябрь) [1, с. 13].

Период развития в онтогенезе (возpacm). Левзея сафлоровидная относится к долгоживущим растениям. Весомый вклад в изучение параметров её развития, продуктивности и динамики экдистероидов внесли работы Н.П. Тимофеева с коллегами. Проведено сопоставление динамики содержания экдистероидов в листовых органах растений с морфометрическими показателями надземных органов левзеи сафлоровидной в возрасте 1-28 лет в агропопуляции Астраханской области по календарным годам жизни и возрастным периодам онтогенеза [2, с. 44].

Содержание экдистероидов во взрослых листьях вегетативных побегов минимально в первый год жизни, увеличивалось с возрастом растения и после наступления генеративного периода относитель- но стабилизировалось [29, с. 114]. Так, на примере одной из агропопуляций левзеи сафлоровидной в Архангельской области установлено, что содержание 20 -гидроксиэкдизона в листьях в ювенильном возрасте было 0,06-0,11 \%, в дальнейшем оно возрастало до $0,17-0,44 \%$ за $1-13-$ й годы жизни (имматурный, виргинильный, молодой, взрослый, старый генеративные периоды). Однако на 16-17-й год (у субсенильных растений) содержание 20-гидроксиэкдизона уменьшалось с 0,39 до $0,25(0,19) \%$, что сравнимо с растениями 2-3-го годов [2, с. $45 ; 30$, с. $169-170]$. Далее, с 18-го по 28-й годы жизни растений наблюдалось ежегодное наращивание прироста вегетативных органов и продуктивности, были достигнуты самые высокие показатели биосинтеза экдистероидов и их накопления в листовых органах вегетативных побегов за 28 лет онтогенеза $0,56-0,62 \%$. Отмечено, что по результатам исследований за период 1-28 лет наблюдали положительную корреляцию между параметрами развития, продуктивностью и накоплением экдистероидов во взрослых листовых органах [2, с. 45-46].

В семенах левзеи сафлоровидной в онтогенезе замечена аналогичная динамика: максимальное содержание 20-гидроксиэкдизона в семенах совпадало с пиком продуктивности в онтогенезе. У зрелых генеративных растений 6-8 лет снижение продуктивности сочеталось с уменьшением 20 Е в семенах с $0,57 \%$ до $0,47-0,41 \%$. На 9-10-й год у значительной части особей содержание 20-гидроксиэкдизона достигло исходного уровня $0,55 \%$ [29, с. 114$]$.

Биотические факторы. При биосинтезе активных веществ существует динамическая связь между наземными и подземными органами, взаимно влияющими на биосинтез 20-гидроксиэкдизона. Исследования, подтверждающие важность подземных органов в синтезе и накоплении экдистероидов, показали необходимость изучения особенностей формирования и строения эндомикоризы - симбиоза корневой системы экдистероидосодержащих растений с эндофитными грибами. Предполага- 
ют, что прорастание и инфицирование растений микоризообразующими грибами стимулируется корневыми выделениями, содержащими сигнальные молекулы - экдистероиды [28, с. 289]. Жизнедеятельность левзеи сафлоровидной тесно связана с симбиотическими взаимоотношениями с гломусовыми грибами, и при отсутствии антропогенных воздействий эндокризма на корнях присутствует всегда. Замечено, что, контролируя биологическими, технологическими или агрохимическими методами эффективность симбиоза, можно через механизмы взаимодействий микоризы и экдистероидосодержащего растения управлять продуктивностью, биосинтезом и накоплением экдистероидов. Так, сильное негативное влияние оказало внесение свежего навоза - эндокризма в межклеточниках корковой паренхимы и апопласте полностью отсутствовала, блокирование развития симбиотических структур на подземных органах растения привело к торможению роста и развития, снижению продуктивности растения, а также подавлению биосинтеза экдистероидов [28, с. 288].

Антропогенные факторы. Преимуществом левзеи сафлоровидной как высокоэффективного источника корма является наличие её иммуностимулирующих и иммуномодулирующих свойств, обусловленных присутствием биологически активных веществ. Для выращивания биологически активного кормового растения важно создать условия, которые способствовали бы как естественному биосинтезу и накоплению физиологически активных веществ, так и сохранению их исходного содержания в сырье во время процесса заготовки и хранения. $\mathrm{K}$ факторам антропогенного воздействия, влияющим на содержание 20 -гидроксиэкдизона в растительном сырье, относят качество посевного материала, условия выращивания, технологические приемы возделывания, условия уборки и хранения сырья и др.

Отметим также влияние типа пути регенерации на выработку вторичного метаболита 20-гидроксиэкдизона в листьях и корнях левзеи сафлоровидной. Исследо- вали растения, регенерированные посредством прямого органогенеза (из эксплантов листьев) и непрямого органогенеза через каллусную ткань (из эксплантов рассады), и сравнили их с растениями, выращенными из семян в теплице в течение 3 месяцев. Превосходным потенциалом для накопления 20Е обладали листья, полученные из каллусной культуры, где содержание $20 \mathrm{E}$ равно $0,738 \%$, а в листьях, полученных из семян, - только $0,238 \%$, в корнях обнаружено 0,304\% против 0,202\% [36, с. 96].

Агротехнические приемы (выбор месторасположения при закладке популяции, способ и нормы посева, междурядные обработки, обкашивание краевых участков для создания режима проветривания в травостое, сроки и кратность отчуждения и др.) могут влиять не только на продуктивность левзеи сафлоровидной, но и на содержание и распределение экдистероидов. При сравнении способов посева в Пермском крае определено, что более высокий урожай получен при рядовом способе посева, а при широкорядном посеве урожайность была в 1,7 раза ниже $[15$, с. 22] и максимальный сбор зеленой массы обеспечили посевы с нормой высева 0,4 млн всхожих семян. В Новосибирской области оптимальным способом посева выбран широкорядный с междурядьями 70 см и нормой высева 8-10 кг/га; при этом содержание 20-гидроксиэкдизона в урожае зеленой массы было в среднем 558 г/га с изменчивостью по годам от 400 до 790 г/га при средней урожайности зеленой массы 230 ц/га (разброс от 175 до 332 ц/га) [21, с. 105-106].

На содержание 20-гидроксиэкдизона в растениях влияло внесение удобрений. В 2010 году опубликована работа о влияние высоких и средних доз органических удобрений на накопление экдистероидов. Определено, что на 2-й год после внесения навоза в средних дозах (150 т/га) у растений 3-го года в середине июня содержание 20 Е составило $0,052 \%$, что в 4,3 раза ниже контроля, а у растений среднегенератив- 
ного возраста оно было $0,12 \%$ против $0,507 \%$, разница в 4,2 раза. И только через 3 года уменьшение синтеза и накопления $20 \mathrm{E}$ снижалось - во время отрастания разница сокращалась до 1,3 ра3, 0,289\% против $0,368 \%$ в контроле [28, с. 289$]$.

После внесения компоста в больших дозах $(500$ т/га) у растений 10-11-го годов жизни в начале цветения содержание 20Е в листьях было ниже на порядок - в 9,4 раза: $0,039 \%$ против $0,366 \%$ в контроле. В более поздние сроки, во время осенней вегетации, экдистероиды полностью отсутствовали, при этом в контроле их было $0,18 \%$. Поверхностное нанесение активного ила в средних дозах (80 т/га) до начала вегетации во время бутонизации привело к снижению накопления $20 \mathrm{E}$ в 1,2 раза - $0,9 \%$ против $0,24 \%$ в контроле. Таким образом, при внесении органических удобрений (навоза, компоста, активного ила) в высоких и средних дозах наблюдалось снижение биосинтеза экдистероидов в 3-10 раз [33, с. 139].

Предположили, что высокие дозы органических удобрений вызывают блокирование развития симбиотических структур на подземных органах экдистероидсодержащий растений, что приводит к торможению роста и развития, снижению продуктивности, а также подавлению биосинтеза экдистероидов. Наиболее сильное отрицательное воздействие оказывает прямой метод внесения органических удобрений в корнеобитаемую зону, при котором биосинтез экдистероидов снижается в 5-10 раз [28, с. 289].

Продуктивность левзеи сафлоровидной и содержание в ней активных веществ зависит также от соотношения видов и доз вносимых минеральных удобрений. Так, у растений без внесения минеральных удобрений отмечалось отставание в развитии, а внесение минеральных удобрений обеспечивало положительный эффект. Наибольшая урожайность зелёной массы в Пермском крае была получена за счет внесения азотного и фосфорного удобрений $\mathrm{N}_{60} \mathrm{P}_{60}[15$, с. $23 ; 16$, с. 66]. От уровня и взаимного сочетания азота и фосфора в почве зависит и накопление 20-гидроксиэкдизон. Отмечено, что при высоких дозах азота биосинтез экдистероидов может полностью подавляться [25, с. 195]. Разное действие азотно-фосфорных удобрений обусловлено их влиянием на деятельность эндогенной микоризы в зоне корневой системы, принимающей участие в биосинтезе экдистероидов [25, с. 195]. При использовании небольших доз минеральных удобрений, содержащих калий, наблюдалось незначительное снижение количества экдистероидов, на 7-12\% [33, с. 139]. Воздействие фактора минерального питания проявляется через ответную реакцию эндомикоризы в корнеобитаемом слое почвы при высоких концентрациях развитие микоризы подавляется и она полностью отсутствует в верхнем удобренном слое почвы [33, с. 139-140].

Представляет интерес изучение влияние микроэлементов на биосинтез 20-гидроксиэкдизона в левзее сафлоровидной. Например, в работе [6, с. 359] установлено, что растворы солей кобальта, молибдена и марганца благоприятно влияют как на развитие экдистероидсодержащих растений (Silene frivaldskyana и S. linicola), так и на биосинтез 20-гидроксиэкдизона в наземной части. Для увеличения синтеза 20Е проводили предпосевную обработку семян растворами нитрата кобальта и молибдата аммония с концентрацией растворов солей $1 \times 10^{-4} \mathrm{M}$, при которой наблюдалось увеличение содержания 20-гидроксиэкдизона в проростках (в 1,4-1,5 раза выше, чем в контроле). Более концентрированные растворы солей снижали всхожесть семян и уменьшали содержание 20Е. Максимальный уровень 20Е наблюдался при внекорневой обработке нитрата кобальта $(13,5$ мг/г) и корневой обработке сульфатом марганца (11,1 мг/г) [6, с. 359]. Усиленному синтезу 20-гидроксиэкдизона в исследованных экдистероидсодержащих растениях способствовали все виды обработок раствором нитрата кобальта, внекорневая и корневая - сульфатом марганца, предпосевная обработка молибдатом аммония. 
Влияние регуляторов роста растений (фитогормонов). Гормоны растений могут стимулировать рост, деление клеток и биосинтез вторичных метаболитов, в том числе экдистероидов. Среди фитогормонов выделяют несколько групп: ауксины, цитокинины, гиббереллины и абсцизовую кислоту. Сложно определить, какая из групп роста индуцирует синтез экдистероидов, соотношение разных фитогормонов определяет выработку вторичных метаболитов [37, с. 615].

Влияние регуляторов роста и развития на биосинтез экдистерона у левзеи сафлоровидной изучено на примере использования фитогормонов гиббереллин и гетероауксин. Преимущество наблюдалось у гиббереллина, при его использовании накопление экдистерона во взрослых розеточных листьях было выше контроля - 0,23\% против $0,17 \%$ [27, с. 168$]$.

Биосинтез фитоэкдистероидов многоступенчатый метаболический путь. В работе [37, с. 616] показано, что холестерин и его производные - мевалоновая и уксусная кислоты - являются наиболее важными прекурсорами, их добавление позволяет увеличить выход экдистероидов в культуре in vitro.

Условия уборки и заготовки. Сроки и кратность отчуждения фитомассы влияет на содержание экдистероидов [30, с. 168]. Наибольшая концентрация 20-гидроксиэкдизона наблюдалась в самом начале вегетации, однако заготовка сырья в этот период нежелательна, поскольку масса сухих листьев левзеи минимальна [10, с. 25]. В период массовой заготовки в условиях астраханской агропопуляции (30-60 дни вегетации) содержание 20-гидроксиэкдизона во взрослых листьях вегетативных побегов равно $0,27-0,33 \%$, а к концу заготовительного сезона оно снижалось до 0,17 [23, с. 39]. Оптимальным временем заготовки сырья для витебской агропопуляции определен период с первой декады июня по первую декаду июля, это время оптимально по количеству накапливаемого 20-гидроксиэкдизона и динамики развития растения [10, с. 27].
В Белоруссии А.А. Карусевич $[8$, c. 24] рекомендует заготовку листьев производить дважды в течение вегетационного периода путем скашивания надземной части после созревания семян первая декада июля, в конце вегетационного периода - последняя декада августа. В случае отрастания листьев в августе проводить третью уборку до наступления заморозков [11, с. 42].

Левзея сафлоровидная в условиях Пермского края обеспечивала два укоса за сезон с высокой урожайностью и питательностью корма, определены наилучшие сроки скашивания: первый укос в период полной бутонизации - начало цветения, второй укос через 44-60 дней после первого укоса при прекращении линейного прироста [15, с. 23]. В травяной муке из зеленой массы левзеи сафлоровидной, собранной в 2016 г., в первом укосе содержание 20Е было $0,49 \%$, во втором $0,020 \%$; такое низкое содержание связано с ростом растения в период засухи и высоких температур [20, с. 174]. На следующий год в травяной муке, собранной в первом укосе в третьей декаде июня содержание 20-гидроксиэкдизона составило $0,39 \%$ в сухом веществе [19, с. 41$]$.

Н.П. Тимофеевым показано, что интенсивное отчуждение надземной биомассы приводит к снижению величины оттока углеводов в подземные органы и, как следствие, величина биосинтеза экдистероидов при двукратном отчуждении снижается в 2,0-2,5 раза [25, с. 195]. Однако второй укос желателен, поскольку старые листья понижают качество сырья [8, с. 41]. Таким образом, кратность отчуждения фитомассы (количество укосов) может влиять на содержание экдистероидов.

Предполагается, что можно регулировать содержание 20Е в растительном материале через создание оптимального технологического режима и набором агротехнических мероприятий при культивировании с целью наиболее полно реализовать потенциальные возможности накоплений 20гидроксиэкдизона при различных условиях роста и развития [25, с. 196$]$. 
На содержание 20-гидроксиэкдизона в листьях лезвеи сафлоровидной влияет температура сушки. Установлено, что содержание $20 \mathrm{E}$ снижается при увеличении температуры сушки с 20 до $60^{\circ} \mathrm{C}$; предположили, что при этих температурах возможно разрушение 20Е вследствие активности ферментов. При температуре свыше $80^{\circ} \mathrm{C}$ происходит инактивация ферментов и при быстрой сушке в течение 2-3 часов сырье высыхает быстрее, чем происходит термическое разрушение 20гидроксиэкдизона. Предложены оптимальные режимы сушки: без принудительной вентиляции - при температуре $120^{\circ} \mathrm{C}$, с принудительной вентиляцией при температуре $80^{\circ} \mathrm{C}$ [9, с. 81].

Влияние температуры и влажности высушенного сырья на сохранность 20-гидроксиэкдизона было изучено в цельных листьях и в порошке из листьев левзеи сафлоровидной $[18$, с. 47]. Показано, что деструкция 20Е увеличивалась при повышении температуры и с повышением влажности сырья. Наиболее полная сохранность 20-гидроксиэкдизона обеспечивалась при хранении сырья в условиях, допускающих возможность газообмена с внешней средой, при температуре $20^{\circ} \mathrm{C}$, и чуть лучше он сохранялся в измельченных листьях [18, с. 51-53]. Представляет интерес исследование сохранности 20-гидроксиэкдизона при разных температурах и влажности не только в листьях, но и в травяной муке из левзеи сафлоровидной, используемой в качестве корма.

Содержание активных веществ в заготовленном кормовом сырье зависит от условий и сроков хранения. Растительное сырье, прошедшее хорошую первичную обработку на всех этапах заготовки и переработки, тщательно отсортированное от органических и минеральных примесей, способно в течение длительного времени сохранять свои функциональные свойства. Например, в листьях после 5 лет хранения в грубоизмельченном виде концентрация 20-гидроксиэкдизона составляла $0,15-0,18 \%$, через 10 лет $-0,10-0,12 \%$ [23, с. 40].
Отмечено, что на сохранность 20-гидроксиэкдизона в левзее сафлоровидной оказывало влияние загрязнение примесями, инфицированными микрофлорой. Так, при измельчении загрязненных корней с корневищами в течение нескольких месяцев они теряли качество, и через год хранения количество $20 \mathrm{E}$ уменьшалось вдвое: с $0,10 \%$ до $0,05 \%$, а через 2 года оставались лишь следовые количества. Сырье из надземных частей, загрязненное аналогично корням, могло в течение нескольких месяцев потерять 20-гидроксиэкдизон на порядок с $0,2-0,3 \%$ до $0,004-0,03 \%$ [23, с. 40$]$.

Условия хранения сухих листьев, корней и корневищ левзеи сафлоровидной в качестве лекарственного сырья нормируются для сохранения содержания 20-гидроксиэкдизона в количестве не менее $0,1 \%$. Хранение допускается в защищенном от влаги и света месте при температуре от +15 до $+25^{\circ} \mathrm{C}$ [5, с. 368-369]. С целью прогнозирования сроков годности при различных условиях хранения предложен метод определения сроков годности в сырье левзеи сафлоровидной на основе стресс-теста «ускоренное старение» [18, с. 47].

Факторы и условия, которые в разной степени могут влиять на направленность метаболических процессов в растениях, способных изменять биосинтез и накопление биологически активных веществ в кормовой культуре, приведены в таблице. В данной работе остановились на нескольких из них.

Заключение. На основании анализа литературных данных сделан вывод, что в период с 2005 по 2019 г. исследования по биосинтезу, накоплению и сохранности 20гидроксиэкдизона в левзее сафлоровидной продолжаются и тема остается актуальной.

Показано, что на содержание 20-гидроксиэкдизона в разной степени влияют факторы абиотической среды (температура, влажность, освещенность, почва), антропогенного воздействия (условия выращивания, удобрения, условия заготовки, сушки и хранения), вегетация, онтогенез и др. 


\begin{tabular}{|c|c|}
\hline \multicolumn{2}{|r|}{ Факторы, влияющие на содержание 20-гидроксиэкдизона } \\
\hline Группа фракторов & Факторы \\
\hline \multicolumn{2}{|r|}{ Экологические фракторы } \\
\hline \multicolumn{2}{|r|}{ ффакторы абиотической среды } \\
\hline Климатические & $\begin{array}{l}\text { свет (интенсивность, спектр, продолжительность, периодичность), } \\
\text { температура (величина, периодичность), } \\
\text { влажность воздуха, атмосферные осадки, газовый состав воздуха, радиационный } \\
\text { фон и др. }\end{array}$ \\
\hline $\begin{array}{l}\text { Эдафические (почвенно- } \\
\text { грунтовые) }\end{array}$ & $\begin{array}{l}\text { состав почвы (гранулометрический, химический), } \\
\text { влажность почвы, воздухопроницаемость почвы, аэрация, кислотность почвы, } \\
\text { плотность почвы и др. }\end{array}$ \\
\hline топографические & $\begin{array}{l}\text { орографичческие фракторы, фракторы рельефра, высота над уровнем моря, крутизна } \\
\text { и экспозиция склона }\end{array}$ \\
\hline \multicolumn{2}{|r|}{ факторы биотической среды } \\
\hline Биотические & $\begin{array}{l}\text { фитогенные (конкуренция), микогенные (симбиоз, эндокризмы), микробиогенные, } \\
\text { фитофрагогенные (паразитизм, поражение насекомыми), зоогенные (хищничество) }\end{array}$ \\
\hline \multicolumn{2}{|r|}{ факторы антропогеннье } \\
\hline Посевной материал & вид, сорт, репродукция, пути регенерации \\
\hline $\begin{array}{l}\text { Условия выращивания } \\
\text { элементы технологии } \\
\text { возделывания }\end{array}$ & $\begin{array}{l}\text { сроки сева, способ и густота посева, норма посева, орошение, } \\
\text { органические и минеральные удобрения, микроэлементы, прекурсоры, } \\
\text { регуляторы роста (фитогормоны) }\end{array}$ \\
\hline Условия уборки урожая & $\begin{array}{l}\text { сроки и способы уборки, кратность отчуждения фитомассы (количество укосов) и } \\
\text { др. }\end{array}$ \\
\hline $\begin{array}{l}\text { Условия хранения } \\
\text { урожая }\end{array}$ & $\begin{array}{l}\text { подготовка к хранению, виды, способы и режимы обработки, условия сушки, } \\
\text { способы, режимы и организация хранения }\end{array}$ \\
\hline \multicolumn{2}{|r|}{ Биологические особенности } \\
\hline Вегетация & фазы отрастания, бутонизации, цветения, плодоношения, вегетации \\
\hline Онтогенез & $\begin{array}{l}\text { возраст ювенильный, имматурный, виргинильный, генеративный (молодой, } \\
\text { взрослый, старый), субсенильный, сенильный возраст }\end{array}$ \\
\hline Органы растений & $\begin{array}{l}\text { вегетативные и генеративные, } \\
\text { соцветие (цветоложе, семена), побег (листья, стебли, почки), корни }\end{array}$ \\
\hline \multicolumn{2}{|r|}{ Факторы стресса (неблагоприятные фракторы среды) } \\
\hline Биотические & фитопатогены, травоядные животные, конкуренция между растениями \\
\hline Абиотические факторы & $\begin{array}{l}\text { температура (высокая, низкая - холод, мороз), } \\
\text { вода (засуха, переувлажнение - гипоксия), } \\
\text { радиация (освещенность, УФ-излучение, ионизирующее излучение), } \\
\text { химические вещества (дефицит или избыток питательных веществ), поллютанты } \\
\text { (тяжелые металлы, пестициды), вредные газы, } \\
\text { механические факторы (ветер, перемещение почвы, навалы снега, наледи), } \\
\text { другие факторы (электрические поля, магнитные поля) }\end{array}$ \\
\hline
\end{tabular}

Малоизученными остаются вопросы участия микроэлементов в биосинтезе вторичных метаболитов левзеи сафлоровидной и роль факторов стресса, таких как тяжелые металлы, вредные газы, электрические и магнитные поля в накоплении и сохранение экдистероидов.

Представляет интерес продолжить исследования влияния вышеперечисленных факторов на содержание 20-гидроксиэкдизона не только в листьях, но и в травяной муке из зелёной массы левзеи сафлоровидной, используемой для скармливания животным в условиях Пермского края. Полученные сведения позволят прогнозировать и оказывать влияние на рост растений и направленность в них метаболических процессов, способных изменять биосинтез и накопление биологически активных веществ в перспективном кормовом растении, обладающем иммуностимулирующими, иммуномодулирующими и адаптогенными свойствами.

\section{Библиографический список}

1. Беспаева А.М., Тулеуов Б.И., Хабдолда Г. [и др.] Распределение 20-гидроксиэкдизона и его аналогов в растениях // Вестник Карагандинского университета. Сер. Химия. - 2012. - № 2 (66). - С. 12-15. 
2. Биндасова T.Н., Тимофеев Н.П. Морфологические параметры, продуктивность и динамика экдистероидов у Rhaponticum carthamoides в возрасте 1-28 лет // Перспективы развития и проблемы современной ботаники: материалы IV (VI) Всероссийской молодежной конференции с участием иностранных ученых. - 2018. - С. 43-46.

3. Васильев А.С., Абдрашитова (Поломеева) Н.Ю., Удут В.В. Экдистероиды и их биологическая активность // Растительные ресурсы. - 2015. - Т. 51. - № 2. - С. 229-259.

4. Волошин В.А., Матолинеи Д.А., Морозков Н.А., Майсак Г.П. Роль левзеи сафлоровидной в кормлении молочных коров // Сибирский вестник сельскохозяйственной науки. - 2019. - Т. 49. - № 5. - С. 52-60.

5. Государственная фармакопея Республики Беларусь: В 3 т. Т. 2 Общие и частные фармакопейные статьи / УП «Центр экспертиз и испытаний в здравоохранении»; под общ. ред. А.А. Шерякова Молодечно: Победа, 2008. - 472 с.

6. Зибарева Л.Н., Мунхжаргал Н. Влияние микроэлементов на всхожесть семян, развитие проростков и содержание 20-гидроксиэкдизона в надземной части Silene frivaldskyana и S. Linicola (caryophyllaceae) // Растительные ресурсы. - 2014. - № 3. - С. 359-367.

7. Каранкевич Е.Г., Агабалаев А.А., Попова О.П., Куваева З.И. Экстракция 20-гидроксиэкдизона из травы левзеи сафлоровидной // Весці Нацыянальнай акадэміі навук Беларусі. Серыя хімічных навук. - 2012. - № 2. - С. 50-54.

8. Карусевич A.A. Культивирование левзеи сафлоровидной с целью получения надземной фитомассы // Вестник фармации. - 2005. - № 3 (29). - С. 20-26.

9. Карусевич А.А., Моисеев Д.В., Бузук Г.Н. Влияние условий сушки на содержание 20-гидроксиэкдизона в листьях левзеи сафлоровидной // Вестник фармации. - 2008. - № 2 (40). - С. 79-82.

10. Карусевич А.А., Моисеев Д.В., Бузук Г.Н. Изучение динамики накопления 20-гидроксиэкдизона и определение времени заготовки листьев левзеи сафлоровидной // Вестник фармации. - 2008. № 1 (39). - C. 24-28.

11. Карусевич А.А., Осочук С.С., Бузук Г.Н. Разработка методики культивирования и изучение особенностей развития левзеи сафлоровидной в Витебской области // Вестник фармации. - 2016. № 4 (74). - C. 38-44.

12. Кондратьев М.Н., Роньжина Е.С., Ларикова Ю.С. Влияние абиотических стрессов на метаболизм вторичных соединений в растениях // Науч. журн. «Известия КГТУ》. - 2018. - № 49. - С. 203-219.

13. Латушкина Н.А., Ивановский А.А., Тимкина Е.Ю. Исследование химического состава и токсических свойств фитокомплекса, содержащего биологически активные вещества // Аграрная наука ЕвроСеверо-Востока. - 2017. - № 4 (59). - С. 58-62.

14. Мамырова С.А., Казымбетова А.А., Ихсанов Е.С. [и др.] Сравнительный фитохимический анализ надземной и подземной части Rhaponticum carthamoides (Willd.) Iljin // Химический журнал Казахстана. - 2015. - № 2. - С. 331-336.

15. Матолинеи Д.А., Волошин В.А. Биологические особенности и элементы возделывания левзеи сафлоровидной в условиях Пермского края // Кормопроизводство. - 2018. - № 1. - С. 21-24.

16. Матолинеи Д.А., Волошин В.А. Формирование урожая левзеи сафлоровидной и его качества при разных сочетаниях минеральных удобрений // Сибирский вестник сельскохозяйственных наук. 2017. - T. 47. - № 6 (259). - C. 66-72.

17. Матолинеи Д.А., Волошин В.А. Фотосинтетическая деятельность левзеи сафлоровидной в разные годы пользования // Аграрный вестник Урала. - 2016. - № 03 (145). - С. 12-15.

18. Моисеев Д.В. Новый метод определения сроков годности лекарственного растительного сырья (листьев Rhaponticum Carthamoides) на основе стресс-теста «ускоренное старение» // Рецепт. - 2012. № 2(82). - C. 47-54.

19. Морозков Н.А., Матолинеи Д.А., Сергеев И.В. Использование витаминно-травяной муки из левзеи сафлоровидной при выращивании племенного молодняка КРС // Вестник Пермского научного центра УрО РАН. - 2018. - № 4. - С. 39-45.

20. Морозков Н.А., Сергеев И.В., Сычёва Л.В. Влияние травяной муки из левзеи сафлоровидной на репродуктивную функцию коров // Известия Оренбургского государственного аграрного университета. - 2017. - № 6 (68). - С. 173-175.

21. Сапрыкин В.С., Постников Б.А. Маралий корень - перспективное лекарственное растение для использования в кормопроизводстве // Сибирский вестник сельскохозяйственной науки. - 2010. № (6) (210). - C. 104-107.

22. Тимофеев Н.П., Кокшаров А.В. Влияние почв Европейского Севера на химический состав лекарственного сырья левзеи сафлоровидной // Химия и технология растительных веществ: тез. докл. IV Всерос. науч. конфер. - 2006. - С. 288.

23. Тимофеев Н.П., Лапин А.А., Зеленков В.Н. Оценка качества лекарственного сырья левзеи сафлоровидной методом бромной антиокислительной емкости // Бутлеровские сообщения. - 2006. T. 8. - № 2. - C. 36-41. 
24. Тимофеев Н.П., Чухчин Д.Г., Майер Л.В. Хроматографический анализ сложных составов из экстрактов левзеи сафлоровиддной (Leuzea, Rhaponticum carthamoides) // Лекарственные растения и биологически активные вещества: фитотерапия, фармация, фармакология: Материалы междунар. науч. практ. конф. - 2008. - С. 123-129.

25. Тимофеев Н.П. Биологические основы промышленного возделывания левзеи сафлоровидной и серпухи венценосной в агроценозе [в лекарственных целях] // Эколого-популяционный анализ полезных растений: интродукция, воспроизводство, использование: Материалы докладов $\mathrm{X}$ Междунар. симпозиума. - Сыктывкар, - 2008. - С. 194-196.

26. Тимофеев Н.П. Влияние климатических факторов на рост, развитие и биосинтез экдистероидов в фитомассе Rhaponticum carthamoides // Новые и нетрадиционные растения и перспективы их использования. Материалы VIII Междунар. симпозиума. - М., 2009. - С. 305-308.

27. Тимофеев Н.П. Влияние фитогормонов на распределение экстрактивных веществ и биосинтез экдистерона у левзеи сафлоровидной // Новые и нетрадиционные растения и перспективы их использования. Материалы IX Междунар. симпозиума. - М., РУДН, - 2011. - Т. 1. - С. 165-168.

28. Тимофеев Н.П. Влияние эндомикоризы Rhaponticum carthamoides на биосинтез экдистероидов в надземных органах растения // Химия и полная переработка биомассы леса: тез. докл. - СПб.,2010. - C. $288-290$.

29. Тимофеев Н.П. Накопление и изменчивость содержания экдистероидов в лекарственном сырье левзеи сафлоровидной // Сельскохозяйственная биология. - 2009. - Т. 44. - № 1. - С. 106-117.

30. Тимофеев Н.П. Продуктивность надземной фитомассы и содержание экдистерона в агропопуляции левзеи сафлоровидной за 27 лет онтогенеза // Новые и нетрадиционные растения и перспективы их использования. - 2017. - № S13. - С. 167-170.

31. Тимофеев Н.П. Рост и биосинтез экдистероидов у левзеи сафлоровидной под влиянием эдафических факторов // Сельскохозяйственная биология. - 2010. - Т. 45. - № 5. - С. 98-105.

32. Тимофеев Н.П. Состав 65 аналогов экдистерона из левзеи: их активность и выход из корней, семян и листьев // Новые и нетрадиционные растения и перспективы их использования. - 2017. № S13. - C. 75-77.

33. Тимофеев Н.П. Управление биосинтезом и качественным составом фитоэкдистероидов в условиях агропопуляций // Химия и технология растительных веществ: тез. докл. VII Всерос. науч. конф., Сыктывкар. - 2011. - C. 139-140.

34. Kokoska L., Janovska D. Chemistry and pharmacology of Rhaponticum carthamoides: A review // Phytochemistry. - 2009. - Vol. 70. - 842-855.

35. Martinussen I., Volodin V., Volodina S., Uleberg E. Effect of climate on plant growth and level of adaptogenic compounds in maral root (Leuzea charthamoides (Willd.) DC.), crowned saw-wort (Serratula coronate L.) and roseroot (Rhodiola rosea L.) // The European Journal of Plant Science and Biotechnology. 2010. - P. 72-77.

36. Skata E., Grabkowska R., Sitarek P., Kuzma L., Blauz A., Wysokinska H. Rhaponticum carthamoides regeneration through direct and indirect organogenesis, molecular profiles and secondary metabolite production // Plant Cell, Tissue and Organ Culture (PCTOC). - 2015. - Vol. 123. - P. 83-98.

37. Thiem B., Kikowska M., Malinski M.P. [et.al.] Ecdysteroids: production in plant in vitro cultures // Phytochemistry Reviews. - 2017. - Vol. 16(4). - P. 603-622.

\title{
FACTORS AFFECTING THE CONTENT OF 20-HYDROXYECDISONE IN LEUZEA CARTHAMOIDES (REVIEW)
}

\author{
M.A. Solovyova \\ Perm Scientific Research Institute of Agriculture
}

Data are presented, published in the period from 2005 to 2019, devoted to the study of the influence of factors of the abiotic environment (temperature, humidity, illumination, soil), anthropogenic impact (growing conditions, fertilizers, growth regulators, harvesting, drying and storage conditions), as well as vegetation, ontogenesis and other conditions for the content of 20-hydroxyecdysone in the safflower leuzea. Safflower Leuzea (Rhaponticum carthamoides (Willd.) IIjin) is a promising fodder plant that has immunostimulating and immunomodulatory properties and has a positive effect on metabolic processes. It is important to study the factors and conditions that contribute to both natural biosynthesis and the accumulation of physiologically 
active substances in fodder plants, and the preservation of their original content in raw materials during the harvesting and storage process.

Natural and climatic conditions of Perm Krai are favorable for the growth of Safflower Leuzea. It is assumed that it is possible to regulate the $20 \mathrm{E}$ content in plant material through the creation of an optimal technological regime and a set of agrotechnical methods during cultivation. Stressful situations of short duration can lead to an increase in the content of secondary metabolites in plants in response to environmental influences.

Keywords: Rhaponticum carthamoides, maral root, 20-hydroxyecdysone, factors of the abiotic environment.

\section{Сведения об авторе}

Соловьева Марина Александровна, кандидат химических наук, старший научный сотрудник лаборатории биологически активных кормов, Пермский научно-исследовательский институт сельского хозяйства - филиал Пермского федерального исследовательского центра УрО РАН (Пермский НИИСХ), 614532, Пермский край, Пермский район, с. Лобаново, ул. Культуры, 12; e-mail: mariant@bk.ru 